Review

\title{
Mediterranean cork oak savannas require human use to sustain biod- iversity and ecosystem services
}

\author{
Miguel N Bugalho ${ }^{1,3^{*}}$, Maria C Caldeira ${ }^{2}$, João S Pereira² ${ }^{2}$ James Aronson $^{4}$, \\ and Juli G Pausas ${ }^{5}$
}

${ }^{1}$ Centre for Applied Ecology, Instituto Superior de Agronomia, Tapada da Ajuda, Lisboa, Portugal *(migbugalho@isa.utl.pt); ${ }^{2}$ Centre for Forest Research, Instituto Superior de Agronomia, Tapada da Ajuda, ${ }^{3}$ WWF-Mediterranean Program, Rome, Italy; ${ }^{4}$ Centre d'Ecologie Fonctionnelle et Evolutive, Montpellier, France, and Missouri Botanical Garden, St Louis, MO; ${ }^{5}$ Centro de Investigación sobre Desertificación, Spanish National Research Council, Valencia, Spain

Mediterranean cork oak savannas, which are found only in southwestern Europe and northwestern Africa, are ecosystems shaped by human use of high socioeconomic and conservation value. Characterized by sparse tree cover and a diversity of understory vegetation - ranging from shrub formations to grasslands - that support high levels of biodiversity, these ecosystems require active management and use by humans to ensure their continued existence. The most important product of these savannas is cork, a nontimber forest product that is periodically harvested without requiring tree felling. Market devaluation of, and lower demand for, cork are causing a decline in management, or even abandonment, of southwestern Europe's cork oak savannas. Subsequent shrub encroachment into the savanna's grassland components reduces biodiversity and degrades the services provided by these ecosystems. In contrast, poverty-driven overuse is degrading cork oak savannas in northwestern Africa. "Payment for ecosystem services" schemes, such as Forest Stewardship Council (FSC) certification or Reducing Emissions from Deforestation and Degradation(REDD+), could produce novel economic incentives to promote sustainable use and conservation of Mediterranean cork oak savanna ecosystems in both Europe and Africa.

In a nutshell:

- Mediterranean cork oak savannas are human-shaped ecosystems with high conservation value that are maintained through human use

- The primary economic incentive for the management of these savannas is cork production, but cork prices have fallen in recent years

- Cork oak savannas are threatened by disuse and abandonment in southwestern Europe and by overuse in northwestern Africa

- "Payment for ecosystem services" schemes may create economic incentives that promote the ecological and economic viability of cork oak savannas, and of socioecological systems elsewhere

Anthropogenic influences, including ancestral uses of the land (Foster et al. 2003), affect most ecological communities on Earth, and gradually become a fundamental part of many ecosystems (Seastedt et al. 2008). More than 75\% of all terrestrial ecosystems show such marked evidence of human alteration that they are best perceived as "human-made systems 
with natural ecosystems embedded" rather than "natural systems with human embedded influence" (Ellis and Ramankutty 2008).

Human and ecological systems are integrated in many landscapes (Western 2001). Some of these landscapes have high conservation value; that is, they contain high habitat heterogeneity and are rich in endemic species. Examples include the highly diverse forests of (1) the Mahaweli Basin in Sri Lanka that were developed on ancient rice fields (McNeely 1994) (2) Central and South America that resulted from the afforestation of ancient croplands created by indigenous peoples such as the Maya (McNeely 1994) and cultures of the Amazon Basin (Clement 2006). Selective burning and other forms of forest clearance by native peoples throughout the Americas and Australia have promoted a mosaic of ecosystems in different states of ecological succession, thereby maintaining high levels of biodiversity at the landscape scale (eg Anderson 2005).

The conservation value of human-shaped ecosystems is particularly notable in the Mediterranean Basin, where numerous societies have shaped natural ecosystems for more than $10 \square 000$ years (Blondel 2006), generating many cultures and land uses that have contributed to the landscape diversity now present in the region (Blondel et al. 2010). Indeed, the Mediterranean Basin is one of the world's biodiversity "hotspots" (Myers et al. 2000), partially as a result of the long-term human presence and related activities. The biodiversityrich cork oak (Quercus suber) savannas of the western Mediterranean Basin, which resulted from human-mediated disturbances such as forest clearance (including fire use) and livestock grazing, provide a good example of such a human-shaped ecosystem. Today, the spatial distribution of and tree density within cork oak savannas are decreasing in both southwestern Europe and northwestern Africa (Pereira et al. 2004; Vallejo et al. 2009). These ecosystems are threatened by poor or nonexistent land-management practices in some areas, and by chronic overuse in others.

How can these socio-ecological systems - which are inherently dependent on human use - be conserved? Can novel economic incentives be employed to promote their sustainable use and maintain their conservation value?

\section{Cork oak savannas in the Mediterranean Basin A human-shaped ecosystem}

Currently, cork oak savannas occur in the warmer parts of the humid and subhumid western Mediterranean Basin, covering approximately 1.5 million ha in Europe and 1 million ha in North Africa (Figure 1). They have a sparse tree cover of cork oak (30-60 Q suber trees per hectare), at times mixed with Holm oak (Quercus rotundifolia) and, more rarely, with other tree species (eg Pinus pinaster, Pinus pinea). The understory is a heterogeneous mix of shrub formations interspersed with grasslands, fallows, and, less often, cereal crops (Diaz et al. 1997). These savannas may have been present in prehistory, promoted in part from the use of fire by early humans, as has often happened in other savannas associated with early human occupations (Gil-Romera et al. 2010). Cork oak has competitive advantages over other tree species when facing disturbances such as periodic burning, given its high re-sprouting capability and insulating bark composed of cork (Pausas 1997; Panel 1). 
Cork has been harvested and used by humans since remote antiquity; the first known description, by the Greek philosopher Theophrastus, dates to the 4th century BCE. The Roman poet Virgil (70-19 BCE) noted that soldiers of Latium (a region, located in the western-central Italian Peninsula, associated with ancient Roman civilizations) covered their heads with "stripped bark from trees", an apparent reference to cork oak bark. During the Middle Ages, Portugal exported cork to other European countries (Aronson et al. 2009). However, cork only gained genuine commercial importance in the 18th century, as the need for cork bottle stoppers increased with the expansion of the trade in bottled wine. From the 19th century onward, there was a sustained effort to expand the existing areal extent of cork oak lands - most notably in the Iberian Peninsula - in direct response to the increasing value of cork in international markets (Bugalho et al. 2009).

Traditionally, cork oak savannas are low-input management systems. Cork is manually harvested from living trees once every 9-12 years. A shifting rotation is generally practiced, whereby encroaching shrubs are cleared at intervals of 4-7 years to reduce the risk of severe wildfires and to promote the establishment of pasturelands or annual crops (Pinto-Correia 2000). This rotation creates an ever-changing mosaic of land uses and habitat types of high conservation value (Diaz et al. 1997).

\section{Associated biodiversity}

Cork oak savannas are protected ecosystems under the Pan-European network of protected areas (Natura 2000) and can be considered a "biodiversity-based product system", as defined by the Convention on Biological Diversity. The variety of habitats that coexist within cork oak savanna ecosystems supports a diversity of animal and plant species (Figure 2). Human management has favored habitat heterogeneity and biodiversity at local and regional levels, creating a multiplicity of ecotones (see Blondel [2006]). For example, more butterfly and passerine bird species have been found in cork oak savannas than in adjacent closed-canopy oak woodlands, grasslands, or croplands (Diaz et al. 1997). The long-term habitat continuity offered by the evergreen cork oak trees benefits a wide range of species, whereas the open tree structure and the shrubland-grassland matrix of managed oak savannas provide habitat for several critically endangered species - including the Spanish imperial eagle (Aquila adalberti), the Eurasian black vulture (Aegypius monachus), and the Iberian lynx (Lynx pardinus), among others (Carrete and Donázar 2005).

Mediterranean oak savannas are also crucial for overwintering bird populations. The supply of acorns in oak savannas contribute to attract approximately 70[000 Eurasian cranes (Grus grus) and 6 million woodpigeons (Columba palumbus) to the Iberian Peninsula alone (Diaz et al. 1997). Many other migratory and overwintering birds transiting between northern Europe and Africa also use Iberian and other oak savannas (Blondel et al. 2010).

The understory grasslands found in oak savannas are predominantly composed of annuals that survive the hot and dry Mediterranean summers as seeds in the soil, resulting in a relatively high turnover of plant species composition between years. More than 135 species of vascular plants can be found per 0.1 ha of cork oak savannas (Diaz-Villa et al. 2003), including a diversity of shrub species. 


\section{Contrasting socio-economies}

The Mediterranean Basin has been characterized by high human population densities for millennia, but differences in the intensity of human land use between southern Europe and northern Africa in recent years are differentially affecting cork oak savanna systems. The "active rural population" - the number of economically active persons engaged in agriculture, hunting, forestry, or fishing - is decreasing in southern Europe but is steadily increasing in northern Africa (Figure 3).

Disregard of traditional land-use systems and land abandonment is generally widespread throughout most of Mediterranean Europe. In the European Union (EU), agriculture is supported by a set of programs and subsidies (eg direct payments to farmers, subsidizing exports) known as the Common Agricultural Policy (CAP). Agri-environmental schemes (AES) were also established under CAP to protect biodiversity by reducing the negative effects of agriculture (eg reductions in the use of pesticides and/or fertilizers) and promoting environmentally friendly practices, including traditional farming, through compensating payments to farmers. Because they were rarely integrated with other CAP policies, AES had limited success in counteracting land abandonment trends; for example, landowners in areas that were authorized to receive AES support for maintaining traditional farming could receive higher payments if they converted their croplands to forest plantations (Pinto-Correia 2000).

Moreover, the environmental targets of AES were frequently ill-defined (Baylis et al. 2008).

In Mediterranean Europe, land ownership is predominantly private, and cork harvesting is the primary economic driver for the management of cork oak savannas. Livestock production, mainly cattle, is also a source of income, supported by CAP payments to farmers who own livestock, based on a per-head basis. Although grazing is important to maintain the open savanna structure and to control shrub encroachment, CAP per-head basis payments may encourage overgrazing and lead to tree regeneration failure in some areas. Decreasing revenues, partially due to reduced market prices of cork, are contributing to an increasing trend of land abandonment and subsequent shrub encroachment of cork oak savannas in southwestern Europe. In the absence of human activity, these ecosystems are quickly overgrown by native, flammable shrubs, such as Cistus spp, which in turn promotes an increased risk of severe wildfires (Joffre et al. 1999), loss of habitat heterogeneity, and, ultimately, a decrease in the area's conservation value.

In contrast, persistent human overuse of land and biological resources is common in many parts of northwestern Africa, where national policies are lacking or unable to counteract this trend. In this region, cork oak lands and cork harvests are generally owned by the state but local populations have access to woodland resources, such as fuelwood, which are intensively exploited for subsistence purposes. Overharvesting for fuelwood, overgrazing, and excessive collection of acorns for human and animal consumption are degrading tree cover, reducing oak regeneration, and jeopardizing the ecological sustainability of the system (Berrahmouni et al. 2007; Figure 4). Inappropriate cork stripping, including too frequent harvests and unintentional wounding by unskilled laborers, may damage individual cork oak trees and even result in tree mortality.

In sum, contrasts in the intensity of land use by humans are negatively affecting the ecological and socioeconomic sustainability of cork oak savannas in southwestern Europe and northwestern Africa (Table 1). 


\section{Payment for ecosystem services programs and cork oak savannas}

Although their effectiveness as tools for conservation and sustainable resource management is debatable (eg Nelson et al. 2009), "payment for ecosystem services" (PES) programs are increasingly being applied (Daily and Matson 2008) as a means to mitigate ecosystem mismanagement, the loss of biodiversity, and the reduction in ecosystem services (Bennett and Balvanera 2007). Although various explanations as to what constitutes a PES exist, here it is defined as a reward extended to landholders who provide environmental benefits (eg water quality, biodiversity conservation) through appropriate land management practices (Wunder 2005; Engel et al. 2008). The concept has been applied in various ways, including government payments for watershed and aquifer protection in Mexico and Costa Rica, private payments to landowners for biodiversity protection in Bolivia and Australia, and payments made for carbon (C) sequestration in Ecuador (Engel et al. 2008) - to name just a few examples. Payment may be direct (ie in cash) or indirect (ie in-kind compensations, such as the provision of tree seedlings or beehives) and/or complemented by technical assistance for the development of management plans. Some PES projects generate positive benefits for the conservation of biodiversity, as well as improve human well-being (Tallis et al. 2008). We argue that PES programs can be applied to the conservation and restoration of overused cork oak savanna ecosystems, and extended to savannas where human disuse is endangering the persistence of this socio-ecological system. Conventional conservation instruments (eg protected areas, regulation) and AES have proved insufficient to safeguard cork oak savannas (Pinto-Correia 2000). PES are better adapted to human-shaped ecosystems, because they provide economic incentives for improved management practices and can be used to compensate landholders for clearly defined targets, such as $\mathrm{C}$ storage or other ecosystem services.

\section{Carbon-related services of cork oak savannas}

Similar to other types of savannas (Lehmann 2010), cork oak savannas play an important role in the global C budget. As with old-growth forests (Luyssaert et al. 2008), cork oak savannas accumulate and maintain $\mathrm{C}$ stocks for long periods. For instance, a cork oak savanna with an average tree cover of $30 \%$ may sequester up to $140 \mathrm{~g} \mathrm{C} \mathrm{m}^{-2} \mathrm{yr}^{-1}$ (Pereira et al. 2007), a value within the range of savannas in California (Baldocchi and $\mathrm{Xu} 2004$ ) and tropical areas (Murphy et al. 2010), and close to the range estimated for that of old-growth forests (Luyssaert et al. 2008). Cork harvest is a minor component of the tree $\mathrm{C}$ balance, representing approximately $4 \%$ of the total biomass produced between successive cork extractions, and therefore has negligible effects on ecosystem $\mathrm{C}$ storage (Pereira unpublished).

Both overuse and disuse affect the $\mathrm{C}$ balance of cork oak savannas.

In overused savannas, soil degradation and drought hamper tree regeneration and increase tree mortality, thereby reducing ecosystem C stocks (Tiessen et al. 1998). In unmanaged savannas, shrub encroachment shifts soil $\mathrm{C}$ from below- to aboveground plant biomass, increasing the risk of $\mathrm{C}$ losses through wildfires or other disturbances (Jackson et al. 2002). The reallocation of $\mathrm{C}$ to the shrub layer may facilitate the transition from mild surface fires to severe crown fires, and thus increase $\mathrm{C}$ emissions, while reducing tree growth and the potential for $\mathrm{C}$ sequestration (Murphy et al. 2010). Management for the prevention of severe wildfires 
(Figure 4c) is thus crucial to avoid $\mathrm{C}$ losses and maintain cork production in cork oak savannas; such practices will also benefit biodiversity conservation, thereby allowing for a "bundling" approach to the implementation of PES programs (Wendland et al. 2010).

\section{Mechanisms for cork oak savanna conservation and restoration}

Economic incentives derived through PES schemes that encourage best management practices may contribute to the conservation and sustainable use of cork oak savannas (Figure 5). Such incentives may include product-based PES schemes (Wunder 2005) like the Forest Stewardship Council's (FSC) certification and incentives to promote forest conservation through mitigation of $\mathrm{C}$ emissions, as in the "Reducing Emissions from Deforestation and Forest Degradation and enhancement of carbon stocks" (REDD+)) mechanism (Stickler et al. 2009) or other compliance or voluntary markets of ecosystem services. To be applicable to cork oak savannas, PES programs should favor such practices as maintaining effective levels of oak regeneration, clearance of shrub understory in long rotational periods, maintenance of uneven age classes of trees, and decreasing intensity of land uses (eg Rey Benayas et al. 2008), particularly grazing. PES designs developed for sites in southwestern Europe will likely be different from those created for sites in northwestern Africa. In Europe, PES programs must compensate land users for maintaining management practices that generate added value products (eg FSC-certified cork) or ecosystem services; in North Africa, PES programs must be directed toward improving local livelihoods through the prevention of land overuse and degradation of ecosystem services (eg REDD+).

\section{Forest Stewardship Council certification}

The FSC is a non-governmental organization that was created to promote responsible management of the world's forests by adding market value to forest products generated according to environmental, social, and economic principles (Auld et al. 2008). FSC certification is based on a standard of forest management covering issues that include land tenure, use rights and responsibilities, rights of indigenous peoples, and biodiversity conservation, among others. The FSC standard for certification is flexible, to account for different conditions in different countries through collaboration of stakeholders representing environmental, social, and economic interests (Auld et al. 2008). The process, which is voluntary and conducted at the request of landowners, is based on an independent audit of landholder management practices. Application of FSC certification to the management of cork oak savannas in Portugal, Italy, and Spain is progressing, with $56 \square 000$ ha certified thus far, and is under development in Morocco and Tunisia (Berrahmouni et al. 2009).

In addition to forest management, 26 cork companies worldwide (including 10 in Portugal and seven in the US) have certified their "chains of custody" - the pathways taken by raw and processed materials and products from the forest to the consumer - with the FSC standard. This implies industry compliance in the use of raw materials originating from FSCcertified forests. As a result, FSC-certified cork stoppers are now in demand with several wine producers and bottlers in South Africa, the US, Spain (Berrahmouni et al. 2009), and the UK; for instance, Sainsbury, one of the largest supermarket retailers in the UK, has committed to using only FSC-certified cork stoppers in all of their bottles for store-brand wines . This sort of added market value of FSC certified cork will provide financial incentives for the 
responsible management of cork oak savannas, given that added benefits are expected to outweigh management costs (Berrahmouni et al. 2009).

\section{REDD+ mechanisms}

Approximately $15 \%$ of global $\mathrm{C}$ emissions result from deforestation and forest degradation in the tropics (van der Werf et al. 2009). The REDD+ mechanism aims to avoid C emissions through the provision of financial incentives that reduce the rate of forest clearing and degradation and by increasing $\mathrm{C}$ stocks through regeneration, rehabilitation, or restoration of forests in developing countries. REDD + was recognized as a crucial mechanism for reducing C emissions at the UN Framework Convention on Climate Change meeting in Copenhagen, Denmark, in December 2009, where members agreed to set up an international fund to implement REDD+ programs (UNFCCC 2009). Early financial flows associated with REDD mechanisms reached US\$6 billion, easily surpassing international conservation funding flows, which were below US\$1 billion for the 10-year period 2000-2009 (Stickler et al. 2009).

REDD+ is designed to support large-scale ecological restoration activities (Galatowitsch 2009) that could be applied to degraded and overused northwestern Africa cork oak savannas. It could also fund management practices such as reducing overharvesting of fuelwood, which would increase $\mathrm{C}$ stocks and also benefit biodiversity conservation.

Promotion of more sustainable livelihoods can be achieved through the provision of direct payments or in-kind benefits to rural and local populations (Tallis et al. 2009). Positive social impacts can be generated from REDD+ by, for example, providing compensation or technical assistance to rural communities for the development of alternative energy and livelihood strategies that avoid the overharvesting of fuelwood (Lawlor et al. 2010). Restoration of degraded northwestern African oak savannas would also serve to mitigate the deterioration of ecosystem services, such as water regulation, thereby benefiting local human populations. Both FSC and REDD+ programs indirectly target biodiversity conservation as well.

\section{Other services and possible PES schemes}

Other funding sources for PES may come from user fees, taxes, or voluntary donations (Wunder et al. 2008). In some countries there are existing legal frameworks that could be used in the conservation of cork oak savannas. In Portugal, for instance, a public fund to promote wildfire prevention through best management practices was created through a petrol tax (US $\$ 0.007$ per liter) after the country experienced severe wildfires in 2003. Public funding schemes such as this could be made available to finance best management practices (eg avoiding shrub encroachment) in cork oak savannas using, for example, FSC standards and certification as a validation tool (Lawlor et al. 2010).

Voluntary markets of ecosystem services, where the beneficiary of the service pays directly to the ecosystem manager providing the service, are growing substantially (Wendland et al. 2010). In Victoria, Australia, the government compensates landholders for habitat conservation efforts (Stoneham et al. 2003). Corporations with strong social and environmental responsibility policies are providing funds for biodiversity conservation, as well as targeting water-related ecosystem services. In France, Vittel Nestlé - a water bottling corporation - pays farmers with lands upstream of their facility to conduct agricultural 
practices that preserve water quality (Wunder et al. 2008). In the Iberian Peninsula, where water is scarce and likely to become scarcer (Schroter et al. 2005), many cork oak savannas are situated within watersheds associated with impoundments used for irrigation or located over aquifers (eg cork oak covers 36\% of the main aquifer in Portugal; WWF-Mediterranean unpublished). Water-related PES schemes can potentially be implemented in cork oak savannas, but research linking the effects of management practices on water dynamics is still lacking in these ecosystems. Table 2 summarizes the main features of PES discussed above.

\section{Conclusions}

Human-shaped ecosystems with high conservation value, such as cork oak savannas, can only be maintained through sustainable use based on market viability. Lack of economic incentives to management, due in part to global market devaluation of cork, is leading to land abandonment, biodiversity losses, and degradation of ecosystem services of southwestern European cork oak savannas. In contrast, poverty-driven overuse is endangering northwestern Africa cork oak savannas. Well-designed PES schemes could provide an opportunity to promote sustainable use, conservation, and large-scale restoration of southern and northern Mediterranean cork oak savannas.

\section{Acknowledgements}

We thank C Fontaine, S Cerasoli, C Moura, R Jackson, R Ryel, L Silva, D Porej, and HM Pereira for helpful comments that greatly improved the manuscript. Funding was provided by CREOAK project (EU R\&D Fund project number QLK5-CT-2002-01596) and Portuguese National Science Foundation projects POCTI/AGG/48704/2002, POCI/AGR/63322/2004, and PTDC/AGR-AAM/098790/2008.

\section{References}

Anderson MK. 2005. Tending the wild: native American knowledge and the management of California's natural resources. Berkeley, CA: University of California Press.

Aronson J, Pereira JS, and Pausas JG. 2009. Introduction. In: Aronson J, Pereira JS, and Pausas JG (Eds). Cork oak woodlands on the edge. Washington, DC: Island Press.

Auld G, Gulbrandsen LH, and McDermott CL. 2008. Certification schemes and the impacts on forests and forestry. Annu Rev Env Resour 33: 187-211.

Baldocchi D and Xu L. 2004. Carbon exchange of deciduous broadleaved forests in temperate and Mediterranean regions. In: Griffiths H and Jarvis PG (Eds). The carbon balance of forest biomes. Oxford, UK: Garland Science/BIOS Scientific Publishers.

Baylis K, Peplow S, Rausser G, and Simon L. 2008. Agri-environmental policies in the EU and United States: a comparison. Ecol Econ 65: 753-64.

Bennett EM and Balvanera P. 2007. The future of production systems in a globalized world. Front Ecol Environ 5: 191-98.

Berrahmouni N, Escute X, Regato P, et al. 2007. Beyond cork: a wealth of resources for people and nature. Lessons from the Mediterranean. Rome, Italy: WWF Mediterranean.

Berrahmouni N, Regato P, Ellatifi M, et al. 2009. Ecoregional planning for biodiversity conservation. In: Aronson J, Pereira JS, and Pausas JG (Eds). Cork oak woodlands on the edge. Washington, DC: Island Press.

Blondel J. 2006. The "design" of Mediterranean landscapes: a millennial story of human and ecological systems during the historic period. Hum Ecol 34: 713-29. 
Blondel J, Aronson J, Boudiou JY, and Bœuf G. 2010. The Mediterranean Basin - biological diversity in space and time. Oxford, UK: Oxford University Press.

Bugalho MN, Plieninger T, Aronson J, et al. 2009. Open woodlands: a diversity of uses (and overuses). In: Aronson J, Pereira JS, and Pausas JG (Eds). Cork oak woodlands on the edge. Washington, DC: Island Press.

Carrete M and Donázar JA. 2005. Application of central-place foraging theory shows the importance of Mediterranean dehesas for the conservation of the cinereous vulture, Aegypius monachus. Biol Conserv 126: 582-90.

Clement CR. 2006. Demand for two classes of traditional agroecological knowledge in modern Amazonia. In: Posey DA and Balick MJ (Eds). Human impacts on Amazonia: the role of traditional ecological knowledge in conservation and development. New York, NY: Columbia University Press.

Daily GC and Matson PA. 2008. Ecosystem services: from theory to implementation. P Natl Acad Sci USA 105: 9455-56.

Diaz M, Campos P, and Pulido FJ. 1997. The Spanish dehesas: a diversity of land uses and wildlife. In: Pain D and Pienkowski M (Eds). Farming and birds in Europe: the common agricultural policy and its implications for bird conservation. London, UK: Academic Press.

Díaz-Villa MD, Marañón T, Arroyo J, et al. 2003. Soil seed bank and floristic diversity in a forest-grassland mosaic in southern Spain. J Veg Sci 14: 701-09.

Ellis EC and Ramankutty N. 2008. Putting people in the map: anthropogenic biomes of the world. Front Ecol Environ 6: 439-47.

Engel S, Pagiola S, and Wunder S. 2008. Designing payments for environmental services in theory and practice: an overview of the issues. Ecol Econ 65: 663-74.

Foster D, Swanson F, Aber J, et al. 2003. The importance of land-use legacies to ecology and conservation. BioScience 53: 77-88.

Galatowitsch SM. 2009. Carbon offsets as ecological restorations. Rest Ecol 17: 563-70.

Gil-Romera G, Carrión JS, Pausas JG, et al. 2010. Holocene fire activity and vegetation response in south-eastern Iberia. Quat Sci Rev 29: 1082-92.

Jackson RB, Banner JL, Jobbágy EG, et al. 2002. Ecosystem carbon loss with woody plant invasion of grasslands. Nature 418: 623-26.

Joffre R, Rambal S, and Ratte JP. 1999. The dehesa system of southern Spain and Portugal as a natural ecosystem mimic. Agroforestry Systems 45: 57-79.

Kleijn D and Sutherland WJ. 2003. How effective are European agri-environment schemes conserving and promoting biodiversity? J Appl Ecol 40: 947-69.

Lawlor K, Jenkins A, Olander L, and Murray B. 2010. Expanding the scope of international terrestrial carbon options implications of REDD+ and beyond. Durham, NC: Duke University.

Lehman C. 2010. Savannas need protection. Science 327: 642-43.

Luyssaert S, Schulze E-D, Börner A, et al. 2008. Old-growth forests as global carbon sinks. Nature 455: 213-15.

McNeely J. 1994. Lessons from the past. Biodiv and Conserv 3: 3-20.

Myers N, Mittermeier RA, Mittermeier CG, et al. 2000. Biodiversity hotspots for conservation priorities. Nature 403: 853-58.

Murphy BP, Russell-Smith J, Prior LD, et al. 2010. Frequent fires reduce tree growth in northern Australian savannas: implications for tree demography and carbon sequestration. Glob Change Biol 16: 331-443.

Nelson E, Mendoza G, Regetz J, et al. 2009. Modeling multiple ecosystem services, biodiversity conservation, commodity production, and tradeoffs at landscape scales. Front Ecol Environ 7: 4-11. 
Pausas JG. 1997. Resprouting of Quercus suber in NE Spain after fire. J Veg Sci 8: 703-06. Pereira H (Ed). 2007. Cork: biology, production and uses. Amsterdam, Netherlands: Elsevier. Pereira HM, Domingos T, and Vicente L. 2004. Portugal Millennium Ecosystem Assessment: state of the assessment report. Lisbon, Portugal: Faculdade de Ciências da Universidade de Lisboa.

Pereira JS, Mateus JA, Aires LM, et al. 2007. Net ecosystem carbon exchange in three contrasting Mediterranean ecosystems - the effect of drought. Biogeosciences 4: 791-802.

Pinto-Correia T. 2000. Future development in Portuguese rural areas: how to manage agricultural support for landscape conservation? Land Urb Plan 50: 95-106.

Rey Benayas JM, Bullock JM, and Newton AC. 2008. Creating woodland islets to reconcile ecological restoration, conservation, and agricultural land use. Front Ecol Environ 6: 32936.

Schroter D, Cramer W, Leemans R, et al. 2005. Ecosystem service supply and vulnerability to global change in Europe. Science 310: 1333-37.

Seastedt TR, Hobbs RJ, and Suding KN. 2008. Management of novel ecosystems: are novel approaches required? Front Ecol Environ 6: 547-53.

Stickler CM, Nepstad DC, Coe MT, et al. 2009. The potential ecological costs and cobenefits of REDD: a critical review and case study from the Amazon region. Glob Change Biol 15: 2803-24.

Stoneham G, Chaudhri V, Ha A, et al. 2003. Auctions for conservation contracts: an empirical examination of Victoria's BushTender trial. Australian J Agr Resource Econ 47: 477-500.

Tallis H, Kareiva P, Marvier M, et al. 2008. An ecosystem services framework to support both practical conservation and economic development. P Natl Acad Sci USA 105: 9457-64.

Tallis H, Goldman R, Uhl M, et al. 2009. Integrating conservation and development in the field: implementing ecosystem service projects. Front Ecol Environ 7: 12-20.

Tiessen H, Feller C, Sampaio EVSB, and Garin P. 1998. Carbon sequestration and turnover in semiarid savannas and dry forest. Climatic Change 40: 105-17.

UNFCCC (United Nations Framework Convention on Climate Change). 2009. Subsidiary Body for Scientific and Technical Advice. Methodological guidance for activities relating to reducing emissions from deforestation and forest degradation and the role of conservation, sustainable management of forests and enhancement of forest carbon stocks in developing countries. Held in Copenhagen, Denmark, 7-15 Dec 2009. Draft decision -/CP.15. Copenhagen, Denmark: United Nations.

Vallejo VR, Aronson J, Pausas J, et al. 2009. The way forward. In: Aronson J, Pereira JS, and Pausas JG (Eds). Cork oak woodlands on the edge. Washington, DC: Island Press.

van der Werf GR, Morton DC, DeFries RS, et al. 2009. $\mathrm{CO}_{2}$ emissions from forest loss. Nat Geosci 2: 737-38.

Wendland KJ, Honzák M, Portela R, et al. 2010. Targeting and implementing payments for ecosystem services: opportunities for bundling biodiversity conservation with carbon and water services in Madagascar. Ecol Econ 69: 2093-107.

Western D. 2001. Human-modified ecosystems and future evolution. P Natl Acad Sci USA 98: 5458-65.

Wunder S. 2005. Payments for environmental services: some nuts and bolts. Jakarta, Indonesia: Center for International Forestry Research.

Wunder S, Engel S, and Pagiola S. 2008. Taking stock: a comparative analysis of payments for environmental services programs in developed and developing countries. Ecol Econ 65: 834-52. 
Table 1

Table 1. Examples of human use and main ecosystem services of five cork oak savannas in the Mediterranean Basin

\begin{tabular}{|c|c|c|c|c|c|c|}
\hline Site & Location & Area (ha) & Human use & Drivers & Indicators & Ecosystem services \\
\hline $\begin{array}{l}\text { Akfadou, } \\
\text { Algeria }\end{array}$ & $\begin{array}{l}36^{\circ} 4 I^{\prime} \mathrm{N} \\
04^{\circ} 27 \mathrm{~T}\end{array}$ & 11000 & Overuse & $\begin{array}{l}\text { Overgrazing; } \\
\text { overharvesting of } \\
\text { fuelwood }\end{array}$ & $\begin{array}{l}\text { No natural regeneration; } \\
\text { even-aged woodlands; } \\
\text { oak savanna degradation }\end{array}$ & $\begin{array}{l}\text { Fuelwood; cork; } \\
\text { pasture; prevention of } \\
\text { severe wildfires }\end{array}$ \\
\hline $\begin{array}{l}\text { Maamora, } \\
\text { Morocco }\end{array}$ & $\begin{array}{l}33^{\circ} 5 I^{\prime} \mathrm{N} \\
06^{\circ} 5 I^{\prime} \mathrm{W}\end{array}$ & 70000 & Overuse & $\begin{array}{l}\text { Overgrazing; } \\
\text { overharvesting of } \\
\text { fuelwood and acorns }\end{array}$ & $\begin{array}{l}\text { No natural regeneration; } \\
\text { oak savanna degradation }\end{array}$ & $\begin{array}{l}\text { Fuelwood; cork; } \\
\text { acorns; pasture; } \\
\text { prevention of severe } \\
\text { wildfires }\end{array}$ \\
\hline $\begin{array}{l}\text { Machoqueira } \\
\text { do Grou, } \\
\text { Portugal }\end{array}$ & $\begin{array}{l}39^{\circ} 60^{\prime} \mathrm{N} \\
08^{\circ} 22^{\prime} \mathrm{W}\end{array}$ & 2500 & $\begin{array}{l}\text { Toward } \\
\text { sustainable use }\end{array}$ & $\begin{array}{l}\text { Low grazing; } \\
\text { sustainable } \\
\text { management (eg FSC } \\
\text { certification) }\end{array}$ & $\begin{array}{l}\text { Natural regeneration; } \\
\text { multi-age oak savannas }\end{array}$ & $\begin{array}{l}\text { FSC-certified cork; } \\
\text { pasture; prevention of } \\
\text { severe wildfires; } \\
\text { carbon; biodiversity } \\
\text { conservation }\end{array}$ \\
\hline $\begin{array}{l}\text { Parc Natural } \\
\text { de la Serra } \\
\text { d'Espadà, Spain }\end{array}$ & $\begin{array}{l}39^{\circ} 55^{\prime} \mathrm{N} \\
0^{\circ} 22^{\prime} \mathrm{W}\end{array}$ & 7000 & $\begin{array}{l}\text { Land } \\
\text { abandonment }\end{array}$ & $\begin{array}{l}\text { Shrub encroachment; } \\
\text { no grazing }\end{array}$ & $\begin{array}{l}\text { High risk of crown fires; } \\
\text { natural regeneration }\end{array}$ & $\begin{array}{l}\text { Cork; carbon; } \\
\text { biodiversity } \\
\text { conservation }\end{array}$ \\
\hline $\begin{array}{l}\text { Aspres and } \\
\text { Albères, } \\
\text { France }\end{array}$ & $\begin{array}{l}42^{\circ} 33^{\prime} \mathrm{N} \\
03^{\circ} \mathrm{O} I^{\prime} \mathrm{W}\end{array}$ & 15000 & $\begin{array}{l}\text { Land } \\
\text { abandonment }\end{array}$ & $\begin{array}{l}\text { Shrub encroachment; } \\
\text { no grazing }\end{array}$ & $\begin{array}{l}\text { High risk of crown fires; } \\
\text { natural regeneration }\end{array}$ & Carbon \\
\hline
\end{tabular}

Notes: Drivers related to management practices and indicators to current state of the savannas are also listed. Ecosystem services include services from which people obtain direct benefits (eg cork, pasture) and others (in italics) for which they are not currently compensated (eg long-term carbon storage). Sources: personal knowledge of the authors and examples from Aronson et al. (2009).

Table 2

Table 2. PES mechanisms to compensate landholders for services that they can provide but are not still compensated for in cork oak savannas

\begin{tabular}{llllll}
\hline Targeted & Paid for & Who buys? & Who else benefits? & Who sells? & Mechanism \\
\hline Carbon & $\begin{array}{l}\text { Best management } \\
\text { practices; } \\
\text { oak savanna restoration; } \\
\text { oak regeneration }\end{array}$ & $\begin{array}{l}\text { Government; } \\
\text { corporate sector }\end{array}$ & $\begin{array}{l}\text { Global community; } \\
\text { local community }\end{array}$ & Landholder & $\begin{array}{l}\text { REDD+; FSC; } \\
\text { voluntary market; } \\
\text { compliance market }\end{array}$ \\
\hline Biodiversity & $\begin{array}{l}\text { Best management } \\
\text { practices }\end{array}$ & $\begin{array}{l}\text { Government; } \\
\text { corporate sector; } \\
\text { conservation NGOs }\end{array}$ & $\begin{array}{l}\text { Global community; } \\
\text { local community }\end{array}$ & Landholder & $\begin{array}{l}\text { REDD+; FSC; } \\
\text { voluntary market }\end{array}$ \\
\hline Water & $\begin{array}{l}\text { Best management } \\
\text { practices }\end{array}$ & $\begin{array}{l}\text { Government; } \\
\text { municipalities; } \\
\text { water companies; } \\
\text { downstream users }\end{array}$ & Local farmers; & Landholder & Voluntary market \\
\hline
\end{tabular}

Notes: Carbon storage, biodiversity conservation, and potential water regulation services can be targeted through payment of best management practices. These services can be bought through public (eg government) or private (eg corporations) funds benefitting the global or local communities. In North African countries, local communities, which do not hold the land but exploit the resources, must be rewarded for sustainable management practices that simultaneously enhance their livelihoods. Adapted from Wunder et al. (2008). 


\section{Panel 1. Quercus suber: a tree with a unique bark}

Cork oak is a long-lived (up to 200 years or more) evergreen tree, native to the western Mediterranean Basin (Figure 1). Its outer bark is composed of a compact, elastic, and thermally insulating tissue of dead cells with highly impermeable walls (Pereira 2007). Each year, cork oak trees produce a new cork ring that is not shed naturally. This feature, extremely rare in the plant kingdom, has evolved as protection against the periodic fires common throughout the Mediterranean (Pausas 1997).

Cork is extracted without felling the tree. Once the cork is removed, the original phellogen cells die but another layer of active phellogen differentiates in the outer phloem, maintaining the production of cork. The cork oak tree is unique in its high capability to regenerate a new outer bark after harvest (Pausas 1997). The first cork harvest is conducted when the tree is approximately 30 years old. Thereafter, harvests are practiced at 9- to 12-year intervals, the time necessary for the trees to grow a new layer of bark of ca 30 -mm thick.

Approximately 300 000 tons of cork are harvested annually in the western Mediterranean Basin, 70\% of which is transformed into bottle stoppers. Other products include flooring, insulation material (eg for the external fuel tanks of NASA's Space Shuttle program), clothes and accessories, or decorative objects. Globally, cork is the sixth most important non-timber forest product, with an estimated annual export value of US\$329 million, while processed cork products generate approximately US $\$ 2$ billion in annual revenues (Berrahmouni et al. 2007). However, the use of synthetic stoppers and metal screwcaps increases economic competition with traditional cork stoppers and has contributed to world market devaluation of cork (Aronson et al. 2009), with prices declining approximately $30 \%$ between 2003 and 2009. 


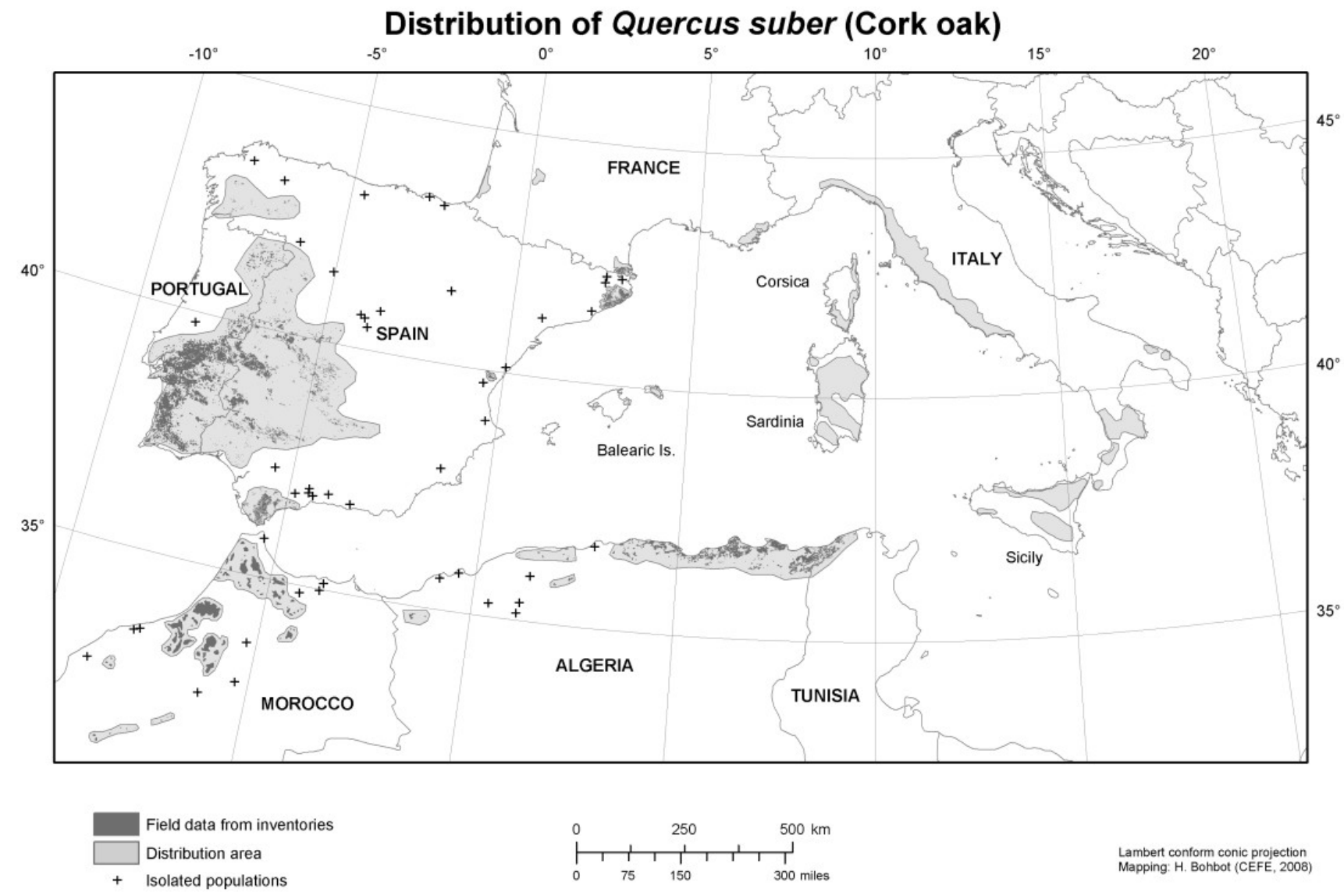

Figure 1. Distribution of cork oak in the western Mediterranean Basin. Reproduced from Aronson et al. (2009), Copyright (C) 2009 Island Press. Reproduced by permission of Island Press, Washington, D.C. 


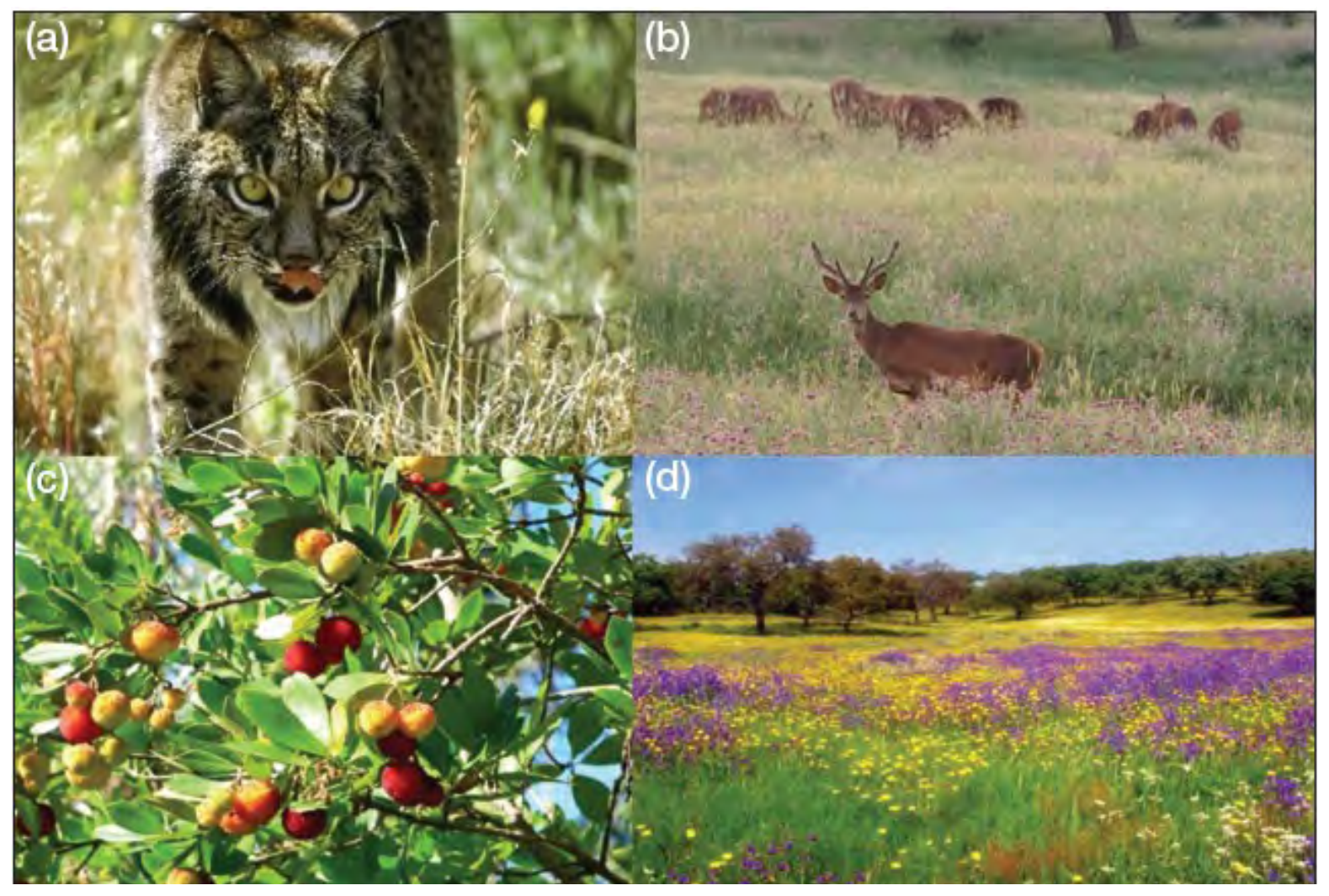

Figure 2. (a) The Iberian lynx (Lynx pardinus), a critically endangered feline, and (b) the North African Barbary deer (Cervus elaphus barbarus), which is the only deer species occurring in North Africa, both use cork oak savannas; (c) shrub species commonly occurring in these savannas include the strawberry tree (Arbutus unedo); (d) Mediterranean grasslands, such as this one in southern Portugal, support a high diversity of species.

Photo credits:
(a) C WWF-Canon / J.Cobo
(b) CWWF-Canon / M. Gunther
(c) F Catry
(d) X Lecomte 


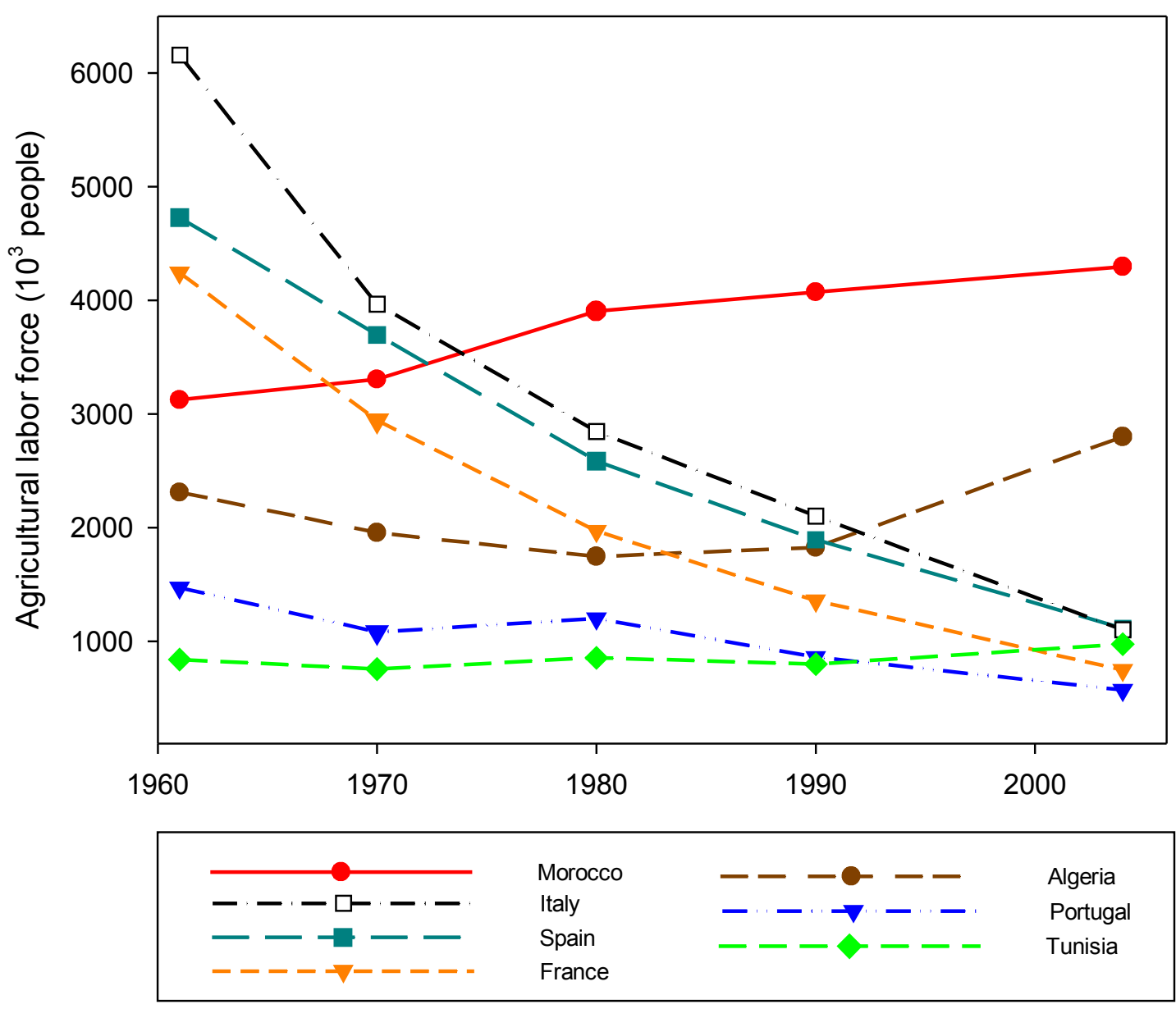

Figure 3. "Active rural population" (see main text) in countries of the western Mediterranean Basin where cork oak savannas occur, 1961-2005. Data obtained from FAOSTAT (http://faostat.fao.org/). 


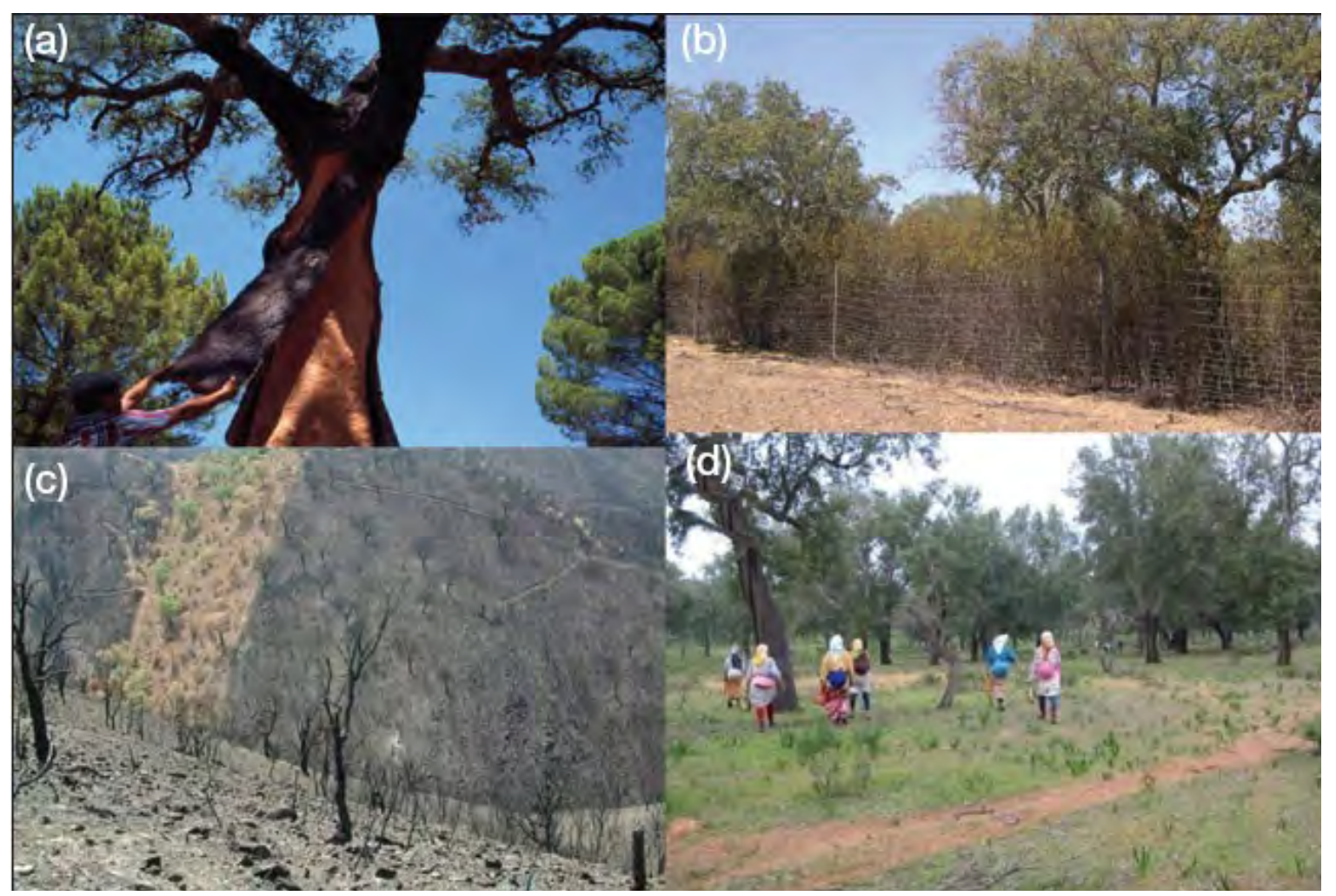

Figure 4. (a) Cork is extracted manually every 9-12 years. (b) After abandonment, the system undergoes shrub encroachment; this fenced plot has been unmanaged for 12 years, and a dense canopy of $C$ ladanifer (averaging $2.5 \mathrm{~m}$ in height) has formed. (c) Cork oak savanna one year after a severe wildfire; the unburned patch was regularly cleared of shrubs by the landholder. (d) A Moroccan site displays evidence of overuse - including oak mortality, a scarcity of juvenile trees, and overgrazing. The women are harvesting acorns.

Photo credits:
(a) APCOR
(b) M Bugalho
(c) P de Jesus
(d) C WWF Mediterranean / N. Berrahmouni 


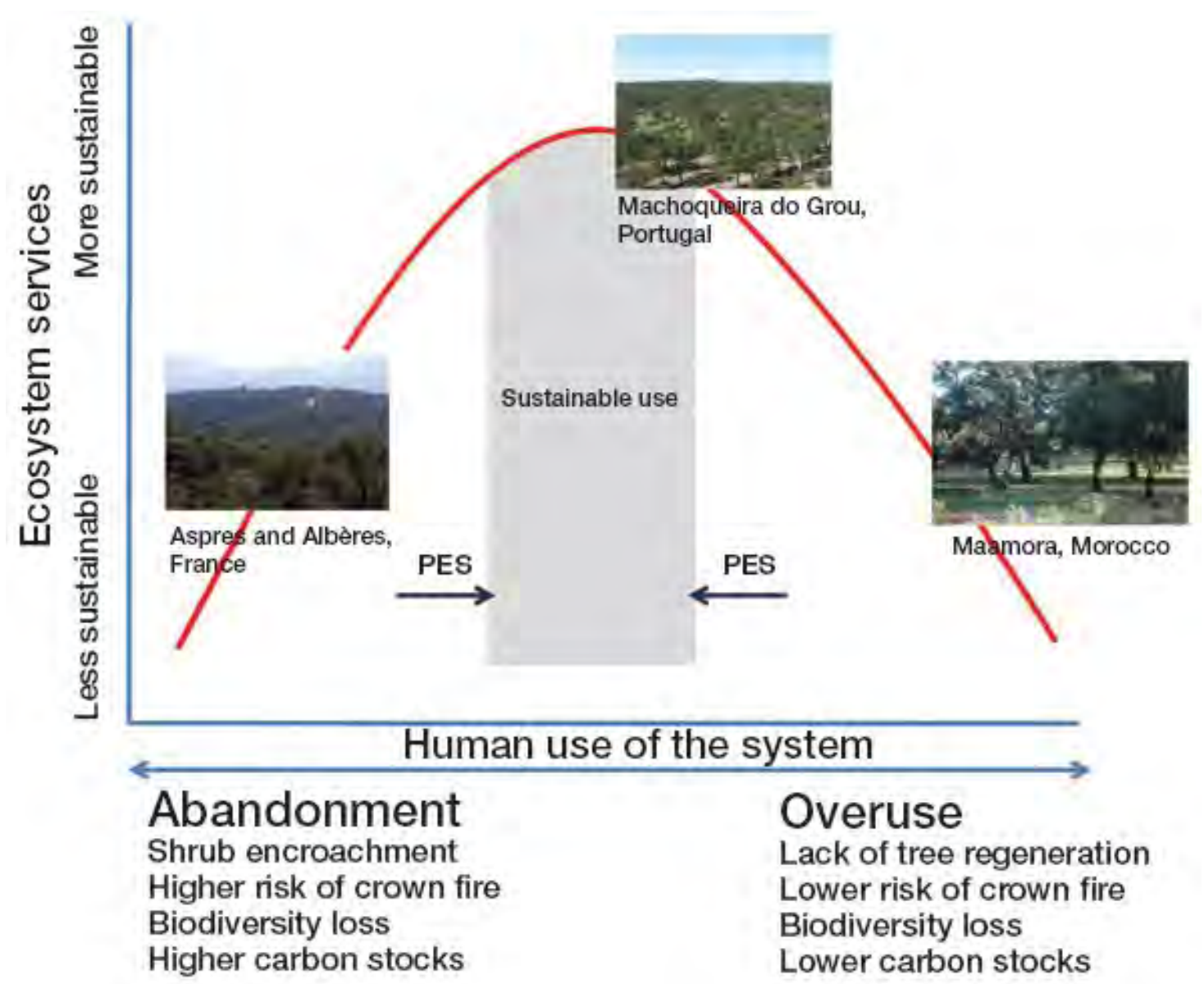

Figure 5. Ecosystem services provided by cork oak savannas depend on the intensity of human use. Both abandonment (eg Aspres and Albères, France) and overuse (eg Maamora, Morocco) are detrimental to biodiversity conservation, but a tradeoff is attained in relation to ecosystem services such as carbon storage. For example, shrub encroachment implies higher aboveground carbon storage but also higher risk of severe wildfires and carbon losses. Sustainable management of the system (eg Machoqueira Grou, Portugal, an FSC-certified site) provides sustained ecosystem services. Application of PES mechanisms may contribute to achieve sustainability. 